\title{
Employee Stock Options Or Tax Nightmares
}

Raj Kiani, (Email:r.kiani@csun.edu), California State University, Northridge Dwight Call, (Email:d.call@ csun.edu), California State University, Northridge M. Sangeladji, (Eamil:m.sangeladji@csun.edu)), California State University, Northridge

\begin{abstract}
In the past several years, many companies, especially in the high-tech, have used incentive stock options as effective means of attracting and maintaining highly qualified employees. With properly designed employees stock options, companies have been able to compensate highly paid executives with a little or no cash out flow. Accepting stock options in lieu of cash compensation has allowed employees to postpone tax on their compensations and to convert the ordinary income to the capital gain income through a later exercise and the sales of their stock options. These benefits can be achieved, if companies set up the stock options properly and employees apply them correctly. Otherwise, employees may get stuck in incentive stock option tax traps depending on the type of stock options. One tax trap related to the Incentive Stock Option (ISO) is a danger of an Alternative Minimum Tax (AMT). The tax trap related to Nonqualified Stock Option (NQSO) is the possibility of a phantom profit. This profit, even though the stock may not have been sold yet by the employees, must be reported by employer to the Internal Revenue Service through employees' $W-2$ form in the year the options are granted or exercised, depending on the prevailing situation. Employees, who exercise this type of options and keep the purchased stocks, may risk watching the stock price decline but still having to pay taxes based on their paper profit.
\end{abstract}

\section{Introduction}

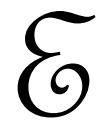

xecutive stock options are effective means of compensating high-paid employees (executives). Through the application of cleverly designed stock options, companies can pay high compensation to certain employees with a built-in mechanism that allows the employees to lower their income tax rate and to delay the payment of their income taxes. From the viewpoint of highly paid employees, the ideal tax option for compensation income is, indeed, the deferral of tax on the income until the time the wherewithal to pay it is readily available and the recognition of income, taxwise, is economically beneficial. In a properly designed employee stock option, such a time usually occurs when stocks are sold, and the gain on the sales of stocks is a long term capital gain. In short, an employee stock option provides an excellent opportunity to employees to acquire equity at a bargain price in lieu of regular cash compensation and pay long-term capital gains tax instead of ordinary income tax at a more opportune date.

From the employers' point of view, the employee stock option is beneficial because it does not require an outflow of corporate cash. Furthermore, it could eventually result in the infusion of cash and capital to the organization. Employee stock options, also, could provide a powerful incentive for employees to contribute to the success of their employers in every way possible, since stock options give employees a financial tie and interest in the long term success of the organization.

Readers with comments or questions are encouraged to contact the authors via email.

The above benefits can be achieved if companies design the stock options correctly and employees apply them wisely. Otherwise, employees can get stuck in unpleasant and unexpected stock option tax traps. The main purposes of this study are to explain: (a) very briefly the kinds of employee stock options and (b) some of the unde- 
sirable tax consequences of stock options for both employee and employer, if applied incorrectly.

\section{Type of Stock Options:}

An employer can use the following types of stock options to compensate its employees:

(1) Incentive stock options-ISO, (statutory)

(2) Nonqualified stock options-NQSO, (non-statutory).

Incentive Stock Option (ISO): ISO is an incentive plan created by the tax law that allows the corporate employer to grant its employees an option to purchase the company's stock at some time in the future at a specified price (strike price). The major legal requirement of an ISO is that the fair market value of stock at the time of grant should be equal or less than the option price (strike price). The other qualification requirements for ISOs are numerous and very complex, but the preferential treatment of ISOs as compared to non-qualifying stock options is straightforward. ${ }^{1}$ The following are some of the general requirements of an ISO plan:

- The option must be granted under a plan specifying the number of shares of stock to be issued and the employees or class of employees eligible to receive the option.

- The option must be granted within 10 years of the date the plan is adopted or of the date the plan is approved by the shareholders, whichever date is earlier.

- The option must by its term be exercisable only within 10 years of the date it is granted.

- The option by its terms must be nontransferable other than at death and must be exercisable during the employee's lifetime only by the employee.

- The employee must not, immediately before the option is granted, own stock representing more than 10 percent of the voting power of all classes of stock in the employer-corporation or its parent or subsidiary. ${ }^{2}$

In an ISO, since the market price of stock is equal or less than the exercise (strike) price at the time of grant, the employee does not recognize the potential bargain element as taxable income ${ }^{3}$ and the corporate employer cannot deduct any compensation expense related to the stock option at that time. ${ }^{4}$ When the market price of the company's stock grows higher than the exercise price, the employee has an incentive to exercise the stock option. At that time (exercise time), the employee should include the difference between the market price and the exercise price for the total number of shares purchased in his/her income tax return as a tax preference item. This inclusion could trigger some additional taxes (Alternative Minimum Tax) or ATM for certain taxpayers. Later on, when the stocks received through the stock option are sold, the employee is required to report the excess of sale proceeds over the exercise price (cost basis of stock) as long-term capital gain.

Holding Period: To be able to take advantage of long-term capital gain treatment, the employee must retain the stock for (1) two years after the option grant date or (2) one year after acquiring the stock. If one of these holding requirements is met, then:

- The gain is long-term capital gain to the employee

- Stock option does not create any deduction for the employer.

In a disqualifying disposition of an ISO, when the disposition of stock takes place prematurely prior to the end of the requisite holding period, the employee recognizes ordinary income as well as capital gain. In this situation, ordinary income is the difference between the option (strike) price and the fair market value (FMV) of stock at the time the option was exercised. The employee should report this ordinary income in the year the option was exercised. The excess of sales proceeds over the fair market value (FMV) of the stock on the date of exercise should be

\footnotetext{
${ }^{1}$ Incentive stock options are defined in Section 422(b).

${ }^{2}$ Hoffman, Smith, and Willis, Individual income taxes, West Federal Taxation, 2002 edition, pp.19-37

${ }^{3}$ The IRC code Section 421(a).

${ }^{4}$ The IRC code Section 421(a)(2)).
} 
included in the employee's income tax return as capital gain in the year of sale. ${ }^{5}$ The holding period of stock after the exercise date determines the nature of gain as either short or long term capital gain. In the case of a disqualifying disposition, the employer is allowed to take a deduction for the amount of recognized ordinary income by the employee. This deduction is for the same year the employee recognizes ordinary income. ${ }^{6}$

Another unpleasant and unexpected consequence of exercising an ISO by employees is the danger of Alternative Minimum Tax (ATM). According to the Los Angeles Times, a former Cisco engineer used incentive stock options to buy about 100,000 Cisco shares last year by paying 5 to 10 cents for each share. At the time, Cisco stock was trading between $\$ 60$ and $\$ 70$ a share. The total difference between the prices he paid to exercise his stock option and the market price of stocks at the time of exercise amounted to about $\$ 6,900,000$. This amount was a preference item and partially taxable to him as income at that time, even though he never sold the shares. ${ }^{7}$ Therefore, under ATM, the first \$175,000 of his taxable income was taxed at a federal $26 \%$ rate, and any amount over that was taxed at $28 \%$. Add in the state income tax his tax liability was approximately $\$ 2,500,000$. At this time, Cisco stock was trading between $\$ 17$ and $\$ 20$ a share, which was less in value than the amount of his tax liability.

There are other limitations and restrictions related to ISO plans. One is the amount of stock that can be exercised by an employee in one year. This amount is $\$ 100,000$ per year by an employee based on the value of the stock at the time the option is granted. ${ }^{8}$ Another restriction concerns the departing employees. In this case, the aforementioned favorable capital gain tax treatment is not available to the departing employee, if the Incentive Stock Option is exercised more than three months after the employee has left the company granting the option.

Nonqualified Stock Option (NQSO): A nonqualified stock option is one that does not meet the statutory requirements of the ISO. One very important requirement, as mentioned before, is that the fair market value of stock at the time of the grant be equal or less than the exercise price. If this condition is not met, the option could end up with some market value. Consequently, such a value at the grant date (paper profit) should be included in the W-2 form of the employee as ordinary income in that year, provided the market value of the option is readily ascertainable on the grant date. In this case, the employer is allowed to record compensation expense in the same year to the extent that the employee recognizes ordinary income. ${ }^{9}$

For most not publicly held corporations, the FMV of their stocks is not readily available, and the FMV of their stock options is not readily ascertainable at the grant date. In this situation, the tax consequence of these nonqualified stock options to the receiving employees is determined at the exercise date rather than the grant date.

When an employee sells stock for which ordinary income was included in his or her W-2 form at the grant or exercise date, a capital gain or loss may emerge. The difference between the FMV of stock and its tax basis determines the amount of reportable gain or loss in that year. The employee's tax basis of the stock is the amount paid for the stock at the exercise date plus any amount reported as ordinary income at the grant or exercise date. Section 83 of the Internal Revenue Service Code governs the tax implications of Nonqualified Stock Options.

\section{Major Advantages of Nonqualified Stock Options:}

- A tax deduction is available to the employer without a cash outlay.

- The employee receives capital gain treatment on any appreciation in the stock starting either at the exercise date if the option does not have a readily ascertainable fair market value (FMV) or at the grant date if the option has a readily ascertainable FMV.

- Options can be issued at more flexible terms than under incentive stock option plans--that is, a longer

\footnotetext{
${ }^{5}$ The IRC code Sections 421(b) and 422(c)(2))

${ }^{6}$ The IRC Section 421(a)(3)).

7 The Los Angeles Times, “Options: Technology Workers Did Not Discover Loophole in Time”, Friday 4/13/2001, p A22.

${ }^{8}$ Hoffman, Smith, and Willis Individual Income Taxes, West's Federal Taxation, 2002 Edition, pp.19-37

${ }^{9}$ Regulations Sections 1.61-2(d)(2)(I); 1.83-4(b)(1) \& Rev.Rul.79-305, 1979-2 C.B.550
} 
exercise period and discount on exercise price. ${ }^{10}$

\section{Major Disadvantages of Nonqualified Stock Options:}

- Employee must recognize ordinary income on the exercise of the option or the date of grant without receiving cash to pay the tax.

- Employees who purchase the shares and do not immediately sell them should pay tax based on their phantom profit while having the risk of watching the stock price decline.

\section{Tax Planning Application}

To analyze the tax consequences of an incentive stock option (ISO) and a nonqualified (NQSO), let's consider the ensuing case of KDS Inc. and its employee, Engineer Joe. In year one, KDS Inc. pays a bonus to Joe by granting him an option to buy 10,000 shares of KDS common stock for a stated (strike) price of $\$ 10$ per share at any time during the next five years. The following scenarios are in order:

\section{Scenario 1: On the date of grant, the strike price of KDS stock ( $\$ 10)$ exceeds the market value of $\$ 8$ per share.}

Since the option has no readily ascertainable value, Joe does not recognize income on receipt of the option. In accepting this option, the only risk for Joe is that the FMV of KDS common does not climb above $\$ 10$ per share over the term of the option. In this case, Joe will let the option lapse and his year one bonus in retrospect becomes worthless.

Assume for the sake of demonstration that this stock option falls under a Nonqualified Stock Option plan, because the employer failed to meet all the requirements of an Incentive Stock Option. Further suppose by the year 5 , the stock price reaches $\$ 60$ per share. At that time, Joe exercises the option by paying $\$ 100,000$ cash to the corporation for 10,000 shares of stock with a FMV of $\$ 600,000$. Consequently, Joe must recognize $\$ 500,000$ bargain element (the excess of FMV over cost) as ordinary income in that case, which will be included in his W-2.

Because of the above transaction, the KDS Corporation can record $\$ 500,000$ as compensation expense in year 5 and treat the \$100,000 cash received from Joe as paid-in-capital. From Joe's viewpoint, he is going to face a negative cash flow in year 5, since he has to pay $\$ 100,000$ for exercising the stock option plus paying both the income and payroll taxes on the $\$ 500,000$ paper profit instead of receiving cash compensation. Joe may have to be forced to sell some of his KDS shares to take care of the negative cash flow. The results are shown in Table 1.

Table 1

ISO CASE versUS NQSO CASE

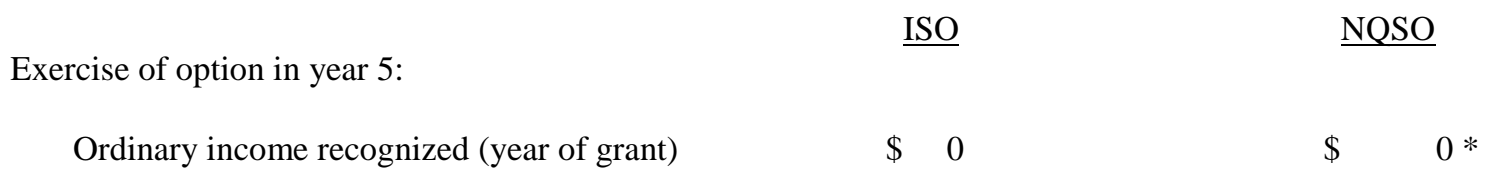

\footnotetext{
${ }^{10}$ Hoffman. W, Smith. J. \&Willis. E. West's Federal Taxation: Individual Income Taxes (SouthWestern College Publishing,2000) p.19-40.
} 
Ordinary income recognized (year of exercise)

Tax at 36\% (depending on employee tax bracket)

Payroll Tax (Minimum of $1.45 \%$ medicare tax)

Alternative Minimum Tax

Basis in 10,000 shares

Sale of stock in year 7 :
900,000

$\underline{100,000}$

800,000

160,000
500,000

180,000

7,250

No

$\$ 600,000$

$\begin{array}{lrr}\text { Selling price } & 900,000 & 900,000 \\ \text { Cost Basis } & \underline{100,000} & \underline{600,000} \\ \text { Capital gain recognized } & 800,000 & 300,000 \\ \text { Income Tax at 20\% } & 160,000 & 60,000\end{array}$

* Assuming the option has no ascertainable FMV on the grant date.

If Joe's employer had met all the requirements of an Incentive Stock Option, Joe would not recognize any income for tax purposes in year 5, when he purchases 10,000 shares of stock worth 600,000 for only $\$ 100,000$. But in year 7, when stocks are sold, Joe recognizes $\$ 800,000$ capital gain of which $\$ 500,000$ represents the untaxed bargain element on exercise of his stock option in KDS Corporation. It should be noted that Joe is subject to an Alternative Minimum Tax in year 5, when he exercises his options. This is a complex area and beyond the scope of this paper. We urge the reader to consult with his or her tax adviser relative to this matter.

From a tax planning point of view, Joe's best alternative is an incentive stock option plan, where he can save a notable amount of taxes, that is $\$ 87,250$ savings in taxes $(\$ 180,000+\$ 60,000+7250-\$ 160,000)$.

\section{Scenario 2: On the date of grant, FMV of stock (\$55) is ascertained and exceeds the strike price of \$10}

Since in this case the option has a readily ascertainable value of $\$ 55$, it is classified as NQSO, and Joe must recognize income on the date he receives the option. Furthermore, if he exercises his option and holds the acquired 10,000 shares of KDS Corporation for the future sales, he could risk observing a decline in the FMV of the stocks. In this situation, Joe could lose significantly because, on one hand, he should pay ordinary income and payroll taxes on his phantom profit. On the other hand, he can deduct only a maximum of $\$ 3,000$ per year against ordinary income since the loss from the sale of stock is a capital loss. Under the tax law capital losses may be offset against capital gains dollar for dollar but may only be deducted against ordinary income by a maximum of \$3,000 per year. So, it might be is wise for Joe to sell the 10,000 shares of stock at $\$ 55$ to avoid the tax nightmare of recognizing paper profit and not deducting the capital loss. The best examples of the previous situation have occurred in many of the Dot.Com companies in the last few years. This was due to heavy usage of employee stock options with Dot. Com companies and the recent decline in the stock prices.

\section{Summary}

Employees can get stuck in a stock option tax trap in one of two ways, depending on the types of employer stock options and the employees' actions. In both kinds of options, Incentive Stock Options (ISO) and Nonqualified Stock Options (NQSO), the tax is based on the difference between the price an employee pays for purchasing stocks through exercising a stock option and the market price of the stocks on the day of sales. However, in a NQSO, the excess of the market price of stock over the exercise price at the date of grant is taxable to the employee as ordinary income and deductible by the employer as compensation expense in the grant year or the exercise year. In a NQSO, thus, a phantom paper profit could be present either at the grant date or the exercise date. The phantom paper profit is reportable to the Internal Revenue Service through the employee's W-2 form in the year the option is granted or exercised, depending on the ascertainability of the fair market value of stock on those days. Employees, who exercise this type of option and keep the purchased stocks longer, may risk watching the stock price rise or decline further. In both cases, the rise or decline in the stock price will generate capital gains or losses. But in the case of de- 
cline in the stock price, the employee has to pay tax on the phantom paper profit on the grant or exercise date and deduct a maximum of \$3,000 of capital losses against ordinary income per year in the year of sale and thereafter.

In an ISO, the tax is more insidious. The paper profit is not recognized as ordinary income for tax purposes in the year of grant. However, an alternative minimum tax may result in the year of exercise. Besides these factors, there is even a tax incentive to hang on to the option since the growth can qualify for a favorable capital gain rate if shares meet the holding period specified by the IRS.

\section{Conclusions}

Stock options are an effective compensation device as long as share prices are rising. When stock prices fall, the options become unexercisable and possibly worthless. In an upward market, options are great. But during a downturn in the market, these underwater options can be ugly and create great tax nightmares for employees. Therefore, employees who receive stock options from their employers must be very familiar with all the ramifications and unpleasant tax consequences of their options. If adequate attention is not exercised, the recipients of employee stock options may face a phantom profit, ordinary income and an alternative minimum tax, on one hand, and capital loss, on the other. We recommend selling the stock immediately upon exercise to avoid the potential disastrous consequences enumerated above.

Notes 